\title{
Evaluation of the Optimized Bioluminescent Assay for the Determination of Total Creatine Kinase and Creatine Kinase MB Activities
}

\author{
By K.-H. Willig' $),$ W. Stein and J. Bohner
}

Abteilung für Innere Medizin IV (Dir. Prof. Dr. M. Eggstein), Medizinische Universitätsklinik Tübingen

(Received February 9/May 2. 1983)

Summary: A very sensitive, optimized bioluminescent assay for creatine kinase and creatine kinase MB activities is tested. We evaluated reagent blanks, sensitivity, precision and compared the results with those of the spectrophotometric immunoinhibition test. The main advantage of the new method is a detection limit of less than $1 \mathrm{U} / 1$ which, together with a high precision $(\mathrm{s}=0.1$ at detection limit), allows determinations of the creatine kinase $\mathrm{MB}$ activity even in normal sera in about 20 minutes. A disadvantage of the manual procedure is that it may be necessary to include up to five pipetting steps.

\section{Evaluierung der optimierten Biolumineszenzmethode zur Bestimmung von Gesamtkreatinkinase- und Kreatinkinase $M B$-Aktivitäten}

Zusammenfassung: Wir berichten über unsere Erfahrung mit der sehr empfindlichen Biolumineszenzmethode zur Bestimmung von Kreatinkinase- und Kreatinkinase MB-Aktivitäten. Insbesondere untersuchten wir Reagentienleerwerte, Sensitivität und Präzision. Darüberhinaus verglichen wir die Ergebnisse dieser neuen Methode mit denen des spektrophotometrischen Immuninhibitionstestes. Der Hauptvorteil der neuen Methode ist in ihrer hohen Empfindlichkeit zu sehen, die Aktivitätsbestimmungen der Kreatinkinase MB selbst in Normalseren innerhalb von 20 Minuten erlaubt. Die Nachweisgrenze für die Kreatinkinase-Aktivität liegt unter $1 \mathrm{U} / /$ bei einer Standardabweichung von 0,1 U/l. Nachteilig ist die manuelle Durchführung mit bis zu fünf verschiedenen Pipettierschritten.

\section{Introduction}

The determination of the activities of creatine kinase $^{2}$ ) and its isoenzyme creatine kinase MB is widely used for the detection of muscle cell damage. The activity of the $\mathrm{MB}$ isoenzyme is especially valuable in the diagnosis of myocardial infarction (1).

1) P.art of the M.D.-thesis of K.-H. Willig.

2) Nonstandard abbreviations used: $\mathrm{CK}=$ Creatine kinase, ATP: Creatine-N-phosphotransferase, EC 2.7.3.2.

CK-MM, CK-MB, CK-BB = skeletal muscle, heart and brain type creatine kinase isoenzymes

AK = Adenylate kinase, ATP:AMP-phosphotransferase, EC 2.7.4.3

Firefly luciferase, EC 1.2.3.-

$s=$ standard deviation.
The optimized bioluminescent assay for creatine $\mathrm{ki}$ nase $\mathrm{MB}$ activity is based on the backward reaction using creatine phosphate and ADP as substrates. Its sensitivity is based on the light-emitting firefly luciferin-luciferase reaction (2) instead of the usual spectrophotometric assay of NADPH. The adenylate kinase problem is circumvented by incorporating inhibitors of adenylate kinase activity (AMP, diadenosine pentaphosphate) into the reaction mixture and by running a blank in which the substrate creatine phosphate is omitted. The specificity of the assay for creatine kinase MB is based on the specific and total inhibition of the creatine kinase $M$ subunits by goat anti creatine kinase $M$ antibodies (3). After inhibition of all $M$ subunits the residual creatine $k i$ - 
nase activity in patients' sera is the result of either creatine kinase $\mathrm{MB}$, creatine kinase $\mathrm{BB}$ or macro creatine kinases. In patients with suspected myocardial infarction this residual creatine kinase activity after immunoinhibition can be regarded as creatine kinase $\mathrm{MB}$ activity, because in this group of patients the occurrence of creatine kinase $\mathrm{BB}(4,5)$ or macro creatine kinases $(6)$ is a rare event.

In the following we describe the results of our evaluation of this bioluminescent assay of creatine kinase with fresh and frozen sera. As a reference method we used a mechanized spectrophotometric immunoinhibition assay.

\section{Materials and Methods}

\section{Principle}

The principle of the bioluminescent assay for the detcrmination of creatine kinase MB is very similar to the spectrophotometric assay. However, apart from the indicator reaction there are other important differences in the concentrations of some reagents: creatine phosphate; ADP concentrations, and the volume fraction of the sample differ widely in both assays. For details see table 1 .

Tab. 1. Reactants and products of the bioluminescent assay of creatine kinase and final concentrations of the reagents $(1,2)$. creatine kinase

Phosphocreatine + ADP $\rightleftharpoons$ creatine kinase $\mathrm{ATP}+$ luciferin $+\mathrm{O}_{2} \stackrel{\text { luciferase }}{\longrightarrow} \mathrm{AMP}+$ pyrophosphate + oxyluciferin $+\mathrm{CO}_{2}+$ light

\begin{tabular}{|c|c|c|}
\hline & $\begin{array}{l}\text { Concentrati } \\
\text { bioluminescent } \\
\text { assay }\end{array}$ & $\begin{array}{l}\text { Ions in the } \\
\text { spectrophoto- } \\
\text { metric assay }\end{array}$ \\
\hline Volume fraction of sample & 0.02 & 0.037 \\
\hline ADP & $0.5 \mathrm{mmol} / \mathrm{l}$ & $2 \mathrm{mmol} / \mathrm{l}$ \\
\hline AMP & $1 \mathrm{mmol} / \mathrm{l}$ & $5 \mathrm{mmol} / \mathrm{l}$ \\
\hline Phosphocreatine & $10 \mathrm{mmol} / \mathrm{l}$ & $30 \mathrm{mmol} / 1$ \\
\hline $\begin{array}{l}\text { Diadenosine penta- } \\
\text { phosphate }\end{array}$ & $0.2 \mu \mathrm{mol} / \mathrm{l}$ & 10 $\mu \mathrm{mol} / 1$ \\
\hline EDTA & $2 \mathrm{mmol} / \mathrm{l}$ & $2 \mathrm{mmol} / \mathrm{l}$ \\
\hline $\mathrm{N}$-acetylcysteine & $20 \mathrm{mmol} / 1$ & $20 \mathrm{mmol} / 1$ \\
\hline $\mathrm{Mg}$ acetate & $10 \mathrm{mmol} / 1$ & 10) $\mathrm{mmol} / \mathrm{l}$ \\
\hline Imidazole acetate & $0.1 \mathrm{~mol} / 1 \mathrm{pH} 6.7$ & $0.1 \mathrm{~mol} / \mathrm{l} \mathrm{pH} 6.7$ \\
\hline Luciferin D-/L- & $100 / 4 \mathrm{mg} / \mathrm{l}$ & $-1-$ \\
\hline Pyrophosphate & $1 \mu \mathrm{mol} / \mathrm{l}$ & - \\
\hline Bovine serum albumin & $1 \mathrm{~g} / \mathrm{l}$ & - \\
\hline ATP standard & $0.1 \mu \mathrm{mol} / \mathrm{l}$ & - \\
\hline Firefly luciferase & + & - \\
\hline
\end{tabular}

The choice of the imidazole buffer is in accordance with the recommendations of the German and Scandinavian Societies for Clinical Chemistry (1) for the optimal reaction conditions of creatine kinase. However, the $\mathrm{pH}$ optimum of luciferase is in the range of $\mathrm{pH} 7.75$ (2), so an internal calibration with known amounts of ATP is included in the reaction sequence to compensate for this different $\mathrm{pH}$ optimum.

Scra studied

The samples were obtained from patients of our hospital. Sera were assayed cither directly or stored at $4{ }^{\circ} \mathrm{C}$ for up to $48 \mathrm{~h}$ or at $-20^{\circ} \mathrm{C}$ with $20 \mathrm{mmol} / 1$ of 2 -mercaptoethanol as additive.

\section{Biolumincscent assay}

Bioluminescence caused by creatine kinase activity was monitored with a Luminometer 1250 connected with a potentiometric recorder 2210, a Teletype printer and a Databox-LuminescenceAnalyzer 1231-001 (LKB-Wallac, Turku, Finland). Temperature of the cuvette (disposable polystyrene tubes, $12 \times 55 \mathrm{~mm}$, Nr. 55484 , W. Sarstedt, Nümbrecht, F.R.G.) and the preincubation bath was held at $25^{\circ} \mathrm{C}$ with a circulating water bath (Haake, Karlsruhe, F.R.G.). Determinations of total activities and creatine kinase $M B$ activities were performed as manual procedures with reagents from LKB-Wallac (No. 1243-101, lots: 13001, 19009, $19013,19014)$. The assays were run with internal ATP calibration standards according to the manufacturer's instructions (LKB No. 13900031) (fig. 1) with the following exceptions:

1. The rate of increase of light emission (slope, S) was measured with the databox for exactly 20 seconds after a 10 seconds lag phase, following the addition of ADP substrate and creatine phosphate substrate $\left(\mathrm{S}_{\mathrm{CK}}, \mathrm{S}_{\mathrm{AK}}\right.$ or $\mathrm{S}_{\mathrm{MB}+\mathrm{AK}}(\mathrm{mV} / \mathrm{min})$ values).

2. After addition of the internal ATP standard, light emission was monitored for exactly 10 seconds with the databox $\left(I_{C K}, I_{A K}\right.$ or

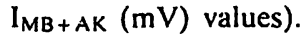

3. Internal calibration with ATP standard was performed in every sample with enzyme activity below $50 \mathrm{U} / \mathrm{l}$. All these ATP standard values $\left(I_{C K}, I_{A K}, I_{M B+A K}\right)$ were reported and an average standard value $\bar{I}$ was calculated daily.

4. In samples with enzyme activities exceeding $50 \mathrm{U} / \mathrm{A}$ the internal calibration and calculation with the databox resulted in imprecise values. Therefore, we had to use the average ATP standard values and to calculate the enzyme activities with a separate calculator:

$$
\begin{aligned}
& \text { CK-MB activity }=\left(\frac{S_{\mathrm{MB}+A K}}{\mathrm{I}_{\mathrm{MB}+\mathrm{AK}}}-\frac{S_{\mathrm{AK}}}{\overline{\mathrm{I}}_{\mathrm{AK}}}\right) \times 20(\mathrm{U} / \mathrm{l}) \text { and } \\
& \mathrm{CK} \quad \text { activity }=\frac{S_{\mathrm{CK}}}{\mathrm{I}_{\mathrm{CK}}} \times 10(\mathrm{U} / \mathrm{l}) .
\end{aligned}
$$

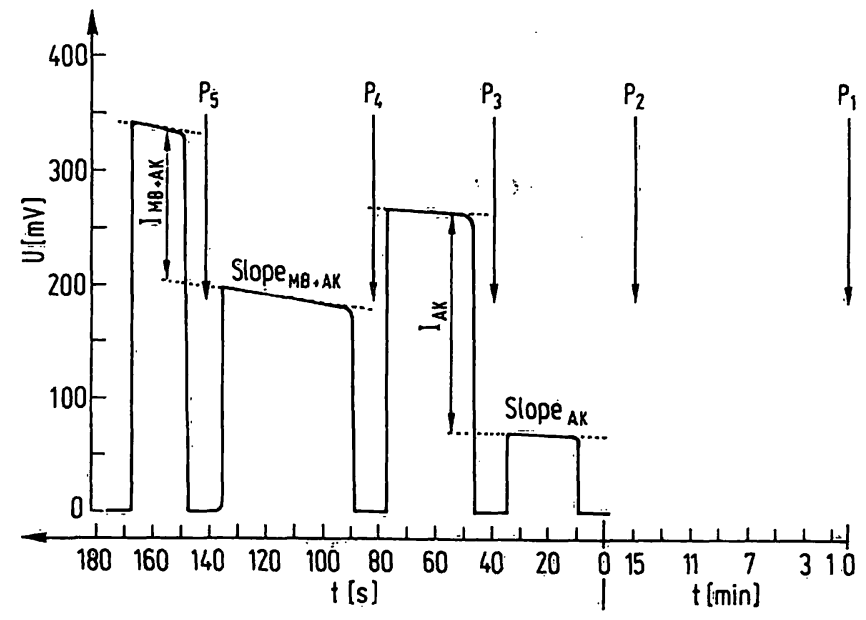

Fig. 1. Determination of creatine kinase MB activity with internal calibration. Bioluminescent assay, time course of light emission curve.

$y$-axis: light intensity $(\mathrm{mV}), x$-axis: time (notice: different time scales).

$P_{1}-P_{5}$ : pipetting steps, indicated by arrows.

$P_{1}$ : CK reagent $(900 \mu \mathrm{l})$, anti-M antibodies $(20 \mu \mathrm{l})$, serum $(20 \mu \mathrm{l})$.

$\mathrm{P}_{2}: 20 \mu \mathrm{l}$ of ADP $(25 \mathrm{mmol} / \mathrm{l})$

$\mathrm{P}_{3}: 20 \mu \mathrm{l}$ of ATP $(10 \mu \mathrm{mol} / \mathrm{l})$

$\mathrm{P}_{4}: 20 \mu \mathrm{l}$ of creatine phosphate $(0.5 \mathrm{~mol} / \mathrm{l})$

Ps: $_{5} 20 \mu \mathrm{l}$ of ATP $(10 \mu \mathrm{mol} / \mathrm{l})$

Slope $_{A K}$ and Slope $M B+A K$ : slopes due to the adenylate kinase and creatine kinase $\mathrm{MB}$ activities ( $\cdots$ )

- $I_{A K}$ and $I_{M B}+A K$ : increase of light emission after internal calibration with ATP standards.

$$
\therefore
$$




\section{Total creatine kinase activity}

We measured total creatine kinase activity with the " $\mathrm{N}$-acetylcysteine reactivated" kit (No. 14109-14111, E. Merck, Darmstadt, F.R.G.) (7) using an ACP 5040 instrument (Eppendorf Gerätebau, Hamburg. F.R.G.).

\section{Immunoinhibition test}

We determined $M B$ isoenzyme activity with " $\mathrm{N}$-acetylcysteine reactivated" reagents (No. 14109, 14110, 14112, E. Merck, Darmstadt. F.R.G.) using an ACP 5040 instrument as described elsewhere (6).

\section{Reagent blanks}

Reagent blanks were determined by pipetting the same volume of $\mathrm{NaCl}$ solution $(154 \mathrm{mmol} / \mathrm{l})$ instead of serum.

\section{Influence of 2-mercaptocthanol}

We appropriately diluted fresh serum with $154 \mathrm{mmol} / \mathrm{I} \mathrm{NaCl}$ solution and detcrmined its creatine kinase activity five times. Subsequently another part of this serum was diluted in the same way but simultaneously we added increasing amounts of 2-mercaptoethanol (range: $0-200 \mathrm{mmol} / \mathrm{l})$. Afterwards the enzyme activities were analysed twice.

Inactivated serum

Heating of normal serum at $56^{\circ} \mathrm{C}$ for $1 \mathrm{~h}$ destroyed all creatine kinase activity. This serum showed a $\mathrm{pH}$ value of 7.45 after heating.

\section{Results}

\section{Reagent blanks and detection limits}

Table 2 shows our results from the determination of the reagent blanks. The detection limits for $20 \mu \mathrm{l}$ of sample volume $(>\bar{x}+3 s)$ were calculated from the data of table 2:

total creatine kinase (LKB): $1 \mathrm{U} / 1$,

creatine kinase $\mathrm{MB}$ (LKB): $1 \mathrm{U} / 1$, creatine kinase MB (Merck, ACP 5040): 3 U/l.

Tab. 2. Reagent blanks.

\begin{tabular}{lllll}
\hline Method & Mean & $\begin{array}{l}\text { Standard } \\
\text { devia- } \\
\text { tion } \\
\mathrm{s}(\mathrm{U} / \mathrm{l})\end{array}$ & $\begin{array}{l}\text { Num- } \\
\text { ber of } \\
\text { runs }\end{array}$ & \\
& $\overline{\mathrm{x}}(\mathrm{U} / \mathrm{l})$ & \\
\hline Total CK (LKB) & 0.7 & 0.09 & 16 & within- \\
CK-MB (LKB) & $0 . \overline{7}$ & 0.11 & 16 & day \\
CK-MB (Merck, ACP) & 0.6 & 0.62 & 25 & \\
Total CK (LKB) & 0.7 & 0.10 & 16 & day-to- \\
CK-MB (LKB) & 0.7 & 0.09 & 16 & day \\
\hline
\end{tabular}

\section{Precision and accuracy}

Within-day precision was determined with fresh sera; day-to-day precision was determined with sera which were kept frozen until the day of the assay, and with commercial reference materials. Results are shown in tables 3 and 4 . The precision of the creatine kinase assay is greatly influenced by the precision of the $I_{C K}$ and $I_{M B+A K}$ values. The higher the creatine kinase activity the higher is the imprecision of the $\mathrm{I}_{\mathrm{CK}}$ values determined by the databox. Therefore, imprecision of the assay significantly increased when creatine kinase activities exceeded $50 \mathrm{U} / \mathrm{l}$. At low creatine kinase $\mathrm{MB}$ activities we found no marked difference between the results obtained with the two modifications of the calculation procedure (using $\mathrm{I}_{M B+A K}$ or $\overline{\mathrm{I}}_{M B+A K}$ ).

Tab. 3. Within-run precision, determined with individual $I_{C K}$ or $\mathrm{I}_{\mathrm{MB}+\mathrm{AK}}$ values (databox) and average $\overline{\mathrm{I}}_{\mathrm{CK}}$ and $\overline{\mathrm{I}}_{\mathrm{MB}}+\mathrm{AK}$ values.

\begin{tabular}{|c|c|c|c|c|c|}
\hline & \multicolumn{2}{|c|}{ Average II } & \multicolumn{2}{|c|}{ Individual I } & \multirow{2}{*}{$\begin{array}{l}\text { Number } \\
\text { of runs }\end{array}$} \\
\hline & $\overline{\mathbf{x}}(\mathrm{U} / \mathrm{I})$ & $s(U / I)$ & $\bar{x}(U / I)$ & $s(U / I)$ & \\
\hline CK (LKB) & $\begin{array}{r}45.8 \\
70.2 \\
99.1 \\
153.2\end{array}$ & $\begin{array}{l}2.0 \\
4.4 \\
6.3 \\
9.2\end{array}$ & $\begin{array}{r}45.5 \\
70.6 \\
100.7 \\
149.9\end{array}$ & $\begin{array}{r}3.3 \\
6.9 \\
15.0 \\
35.7\end{array}$ & $\begin{array}{l}15 \\
16 \\
15 \\
15\end{array}$ \\
\hline \multirow[t]{2}{*}{ CK-MB (LKB) } & $\begin{array}{r}3.3 \\
6.0 \\
22.4\end{array}$ & $\begin{array}{l}0.23 \\
0.41 \\
1.20\end{array}$ & $\begin{array}{r}3.4 \\
5.9 \\
22.2\end{array}$ & $\begin{array}{l}0.43 \\
0.51 \\
1.33\end{array}$ & $\begin{array}{l}15 \\
15 \\
15\end{array}$ \\
\hline & & $\bar{x}(U / I)$ & $\mathbf{s}(\mathrm{U} / \mathrm{l}$ & \multicolumn{2}{|c|}{ Number of runs } \\
\hline \multicolumn{2}{|c|}{ CK-MB (Merck, ACP) } & $\begin{array}{l}14.1 \\
20.2\end{array}$ & $\begin{array}{l}1.7 \\
1.2\end{array}$ & $\begin{array}{l}24 \\
21\end{array}$ & \\
\hline
\end{tabular}

Tab. 4. Day-to-day precision and accuracy.

\begin{tabular}{lcccc}
\hline & & & \multicolumn{3}{c}{$\begin{array}{l}\text { Nium- As- } \\
\text { ber of } \\
\text { runs }\end{array}$} & $\begin{array}{l}\text { signed } \\
\text { value } \\
(\mathrm{U} / \mathrm{l})\end{array}$ \\
& $\bar{x}(\mathrm{U} / \mathrm{l})$ & $\mathrm{s}(\mathrm{U} / \mathrm{l})$ & & \\
\hline Patients' sera & & & & \\
CK (LKB) & 19.0 & 0.96 & 15 & - \\
& 56.9 & 2.84 & 15 & - \\
CK-MB (LKB) & 37.9 & 1.51 & 14 & - \\
& & & & \\
Seronorm & & & & \\
CK (LKB) & $188.6(!)$ & 27.7 & 13 & 398 \\
CK (Merck, ACP) & 389.8 & 14.3 & 20 & 398 \\
CK-MB (LKB) & 37.4 & 2.31 & 14 & 36 \\
CK-MB (Merck, ACP) & 36.6 & 1.69 & 20 & 36 \\
Monitrol & & & & \\
CK (LKB) & & & & \\
CK-MB (LKB) & 53.4 & 2.67 & 14 & 59.4 \\
& 28.9 & 1.23 & 15 & 26.8 \\
\hline
\end{tabular}

Scronorm CK-MB (E. Merck, Darmstadt) lot: 513

$\left(\mathrm{Na}^{+}: 132 \mathrm{mmol} / 1, \mathrm{~K}^{+}: 1.4 \mathrm{mmol} / \mathrm{l}\right.$, phosphate: $0.5 \mathrm{mmol} / \mathrm{l}$, uric acid: $29.7 \mu \mathrm{mol} / 1$, urea: $1.7 \mathrm{mmol} / \mathrm{l}$, creatine: $35 \mu \mathrm{mol} / 1 . \mathrm{Ca}^{2+}$ : $1.9 \mathrm{mmol} / \mathrm{l}$, lactate: $4.0 \mathrm{mmol} / \mathrm{l}$ )

Monitrol I (AHS Deutschland. München) 
Accuracy of the bioluminescent assay may be influenced by serum constituents. This was the case with Seronorm, where it was impossible to reproduce the assigned value for total creatine kinase activity with the bioluminescent assay. The nature of the interfering substance(s) is unknown and the observed influence was not due to urea and creatinine or the electrolytes of this reference material (tab. 4).

\section{Linearity}

We checked linearity by pipetting various sample volumes into the reaction mixture. In contrast to the spectrophotometric assay, in the bioluminescent assay the rate of increase of light emission is independent of the final test volume. Therefore doubling the sample volume doubles the resulting enzyme activity. Creatine kinase activity was linearily related to the sample volumes in a range of at least 5 to $80 \mu \mathrm{l}$ $\left(\mathrm{N}=6 ; \mathrm{y}=0.17+0.67 \mathrm{x} ; \mathrm{r}=0.999 ; \mathrm{s}_{\mathrm{y} \cdot \mathrm{x}}=0.26\right)$ and to at least $0-450 \mathrm{U} / \mathrm{l}$ (results not shown).

\section{Influence of 2 -mercaptoethanol and of sample dilution}

2-Mercaptoethanol: We evaluated possible interference in the luciferase indicator reaction by the widely used thiol-reagent, 2-mercaptoethanol. Table 5 shows that 2-mercaptoethanol does not affect the total creatine kinase activity.

Tab. 5. Influence of 2-mercaptoethanol on the bioluminescent assay.

\begin{tabular}{llllllll}
\hline 2-Mercaptocthanol 0 & 4 & 10 & 30 & 50 & 100 & 150 & 200
\end{tabular} $(\mathrm{mmol} / \mathrm{l})$

$\begin{array}{lllllllll}\text { Creatine kinasc } \quad 75.7 & 75.1 & 77.1 & 76.2 & 75.1 & 74.1 & 71.3 & 74.1\end{array}$ (U/I)

Sample dilution: Dilution of the sample with bovine serum albumin solution (Enzyme Diluent, DuPont, Wilmington, USA), heat inactivated serum or sodium chloride solution and its influence on the resulting creatine kinase activities is shown in table 6.

Tab. 6. Influence of sample dilution on total creatine kinase activity (bioluminescent assay, average of fivefold determinations).

\begin{tabular}{llll}
\hline $\begin{array}{l}\text { Dilution } \\
\begin{array}{l}\text { Serum }+ \\
\text { diluent }\end{array}\end{array}$ & $\begin{array}{l}\text { Diluent } \\
\text { bovine serum } \\
\text { albumin }\end{array}$ & $\begin{array}{l}\text { heat inactivated } \\
\text { scrum }\end{array}$ & $\begin{array}{l}\text { sodium chloride } \\
(154 \mathrm{mmol} / \mathrm{l})\end{array}$ \\
\hline $1+0$ & $1.00(106 \mathrm{U} / \mathrm{l})$ & $1.00(78.9 \mathrm{U} / \mathrm{l})$ & $1.00(115.5 \mathrm{U} / \mathrm{l})$ \\
$1+0.33$ & 1.00 & 1.02 & 1.06 \\
$1+1$ & 1.02 & 1.05 & 1.08 \\
$1+3$ & 1.01 & $1: 09$ & 1.16 \\
$1+4$ & 1.03 & 1.11 & 1.16 \\
$1+9$ & 1.09 & 1.12 & 1.09 \\
\hline
\end{tabular}

\section{Comparison of methods}

Figures 2 and 3 demonstrate the correlation of the results obtained with the bioluminescent assay for creatine kinase $\mathrm{MB}$ with those of the spectrophotometric assay. In every case we plotted the mean of two results obtained with the biojuminescent method

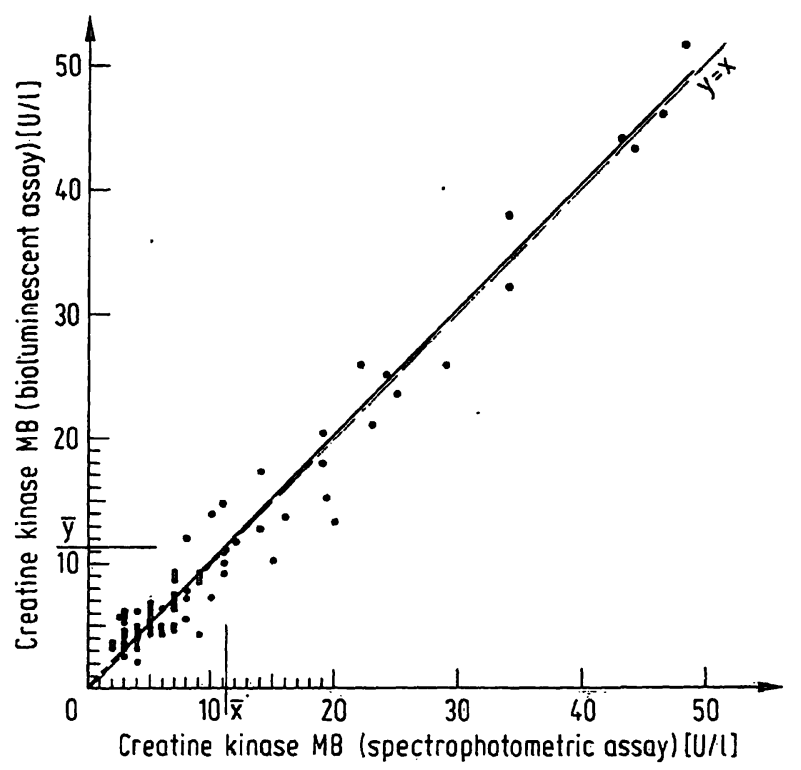

Fig. 2. Correlation between the bioluminescent (y-axis) and the spectrophotometric ( $x$-axis) assays of creatine kinase $M B$ activity. Range: $2-50 \mathrm{U} / \mathrm{l} . \mathrm{N}=76$.

Standardized principle component: $y=0.07+1.00 x ; r=$ $0.98 ; s_{\mathrm{y} . \mathrm{r}}=1.54: \overline{\mathrm{x}}=11.2, \bar{y}=11.3$; there is no significant difference between $\bar{x}$ and $\bar{y}(t-t e s t, 2 P=0.99)$.

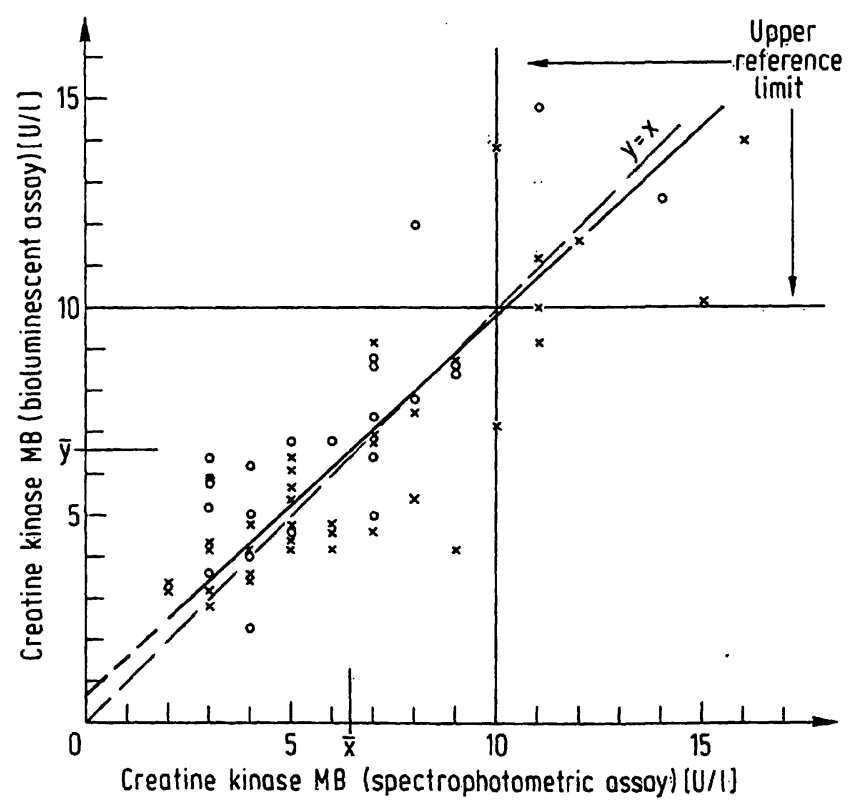

Fig. 3. Comparison of scra with creatine kinase $M B$ activities $<15$ U/1. Y-axis: bioluminescent, $x$-axis spectrophotometric assay. $N=60$ ).

Standardized principle component: $y=0.72+0.92 x ; r=$ $0.82 ; s_{y \cdot x}=1.27 ; \bar{x}=6.5, \bar{y}=6.6 ;$ there exist no significant differences between $\bar{x}$ and $\dot{y}$, and hetween the slope $b$ and 1.00 (t-test. $2 P=0.99$ ).

$x$ : fresh sera; $O$ : sera stored frozen until the day of the assay. 
as a function of only one result obtained with the mechanized spectrophotometric assay. Regression analysis (standard principle component (8)) shows that both methods are in good agreement, even at low creatine kinase MB activities. We found no significant differences between fresh and deep-frozen sera.

Comparison of total creatinc kinase activities by bioluminescent and spectrophotometric assays resulted in almost identical values for both methods. Regression analysis (standard principle component) for sera with enzyme activities between 12 and $450 \mathrm{U} / \mathrm{A}$ yielded the following results: $N=42, \bar{x}=114.4, \bar{y}=$ $116.8, \mathrm{y}=-1.41+1.033 \mathrm{x}, \mathrm{r}=0.99, \mathrm{~s}_{\mathrm{y} \cdot \mathrm{x}}=8.32$. There was no significant difference between $\bar{x}$ and $\bar{y}$ and between the slope $\mathrm{b}$ and 1.00 (t-test, $2 \mathrm{P}=$ 0.99).

\section{Discussion}

Determination of the $\mathrm{MB}$ isoenzyme of creatine kinase by immunoinhibition in sera of patients suspected of having myocardial infarction is commonly accepted. Recently a modification of the spectrophotometric method (3) using firefly-bioluminescence for the indicator reaction was introduced (2). This is claimed to be more sensitive than the spectrophotometric assay, and therefore capable of wider clinical application.

Our purpose was to evaluate the analytical performance of the new kit, and further, to compare its results with those obtained with the spectrophotometric assay. In order to investigate specific properties of the luciferase system, we usually chose only the easier-to-perform total creatine kinase determination. At this stage of evaluation we were not interested in utilizing the high sensitivity of the new system for clinical purposes: e.g. earlier diagnosis of acute myocardial infarction or samples other than serum.

Two steps in the manual bioluminescent assay of total creatine kinase and creatine kinase $\mathrm{MB}$ activities were found to be critical: calibration with the internal ATP standard, and the time at which the slopes are measured. This was especially true if the databox was used for calculation of the results. We recommend that the sudden increase of light emission due to the internal calibration ( $I_{C K}$ or $I_{M B+A K}$ ) be determined after exactly 10 seconds. Otherwise the lag phase of a few seconds (fig. 1) may cause falsely low values for $I_{C K}$ or $I_{M B}+A K$. Furthermore, our experience with creatine kinase activities exceeding 50 $\mathrm{U} / \mathrm{l}$ showed that it is preferable to monitor the slopes due to the creatine kinase reaction for exactly $20 \mathrm{se}$ conds (after a lag phase of 10 seconds) instead of choosing variable measuring times of between 10 and 60 seconds. At shorter intervals creatine kinase activities may be underestimated. This is due to deviations of the linearity of the light emission. At low enzyme activities we saw no significant differences in the precisions using either individual $\mathrm{I}_{\mathrm{CK}}$ and $\mathrm{I}_{\mathrm{MB}+\mathrm{AK}}$ values or the average $\overline{\mathbf{I}}$ for calculating the enzyme activity. In contrast to published results (2) imprecision slightly increased if the individual $I_{C K}$ values were used, but the differences only became significant at higher creatine kinase activities (tab. 3). In these cases the databox determined the individual $I_{C K}$ or $I_{M B+A K}$ rather imprecisely; reliable enzyme activities then could only be achieved with the average $\overline{\mathrm{I}}_{\mathrm{CK}}$ or $\overline{\mathrm{I}}_{\mathrm{MB}+\mathrm{AK}}$ values. Nevertheless, individual internal calibration by ATP standards is useful: some sera (tab. 4) may contain unknown compounds which strongly interfere with the luciferase indicator reaction, leading to surprisingly low $I_{C K}$ values. Only the individual internal calibration can detect such sera and can give an exact result at least for creatine kinase activities up to $40 \mathrm{U} / \mathrm{l}$.

The within-run and day-to-day precisions of the manual bioluminescent assay were high, and at very low creatine kinase $\mathrm{MB}$ activities its coefficient of variation was significantly better than the coefficient of variation of the mechanized spectrophotometric assay. Highly sensitive creatine kinase MB determinations below the upper reference limit are therefore possible. The detection limit of the bioluminescent assay was $1 \mathrm{U} / 1$, but this result is biased by a reagent blank of $0.7 \mathrm{U} / \mathrm{l}$, a value we determined in all of our lots of reagent. If the bias is compensated for by subtracting the constant reagent blank of $0.7 \mathrm{U} / \mathrm{l}$, then the detection limit is lowered to $0.3 \mathrm{U} / \mathrm{l}$. By increasing the sample volume of the bioluminescent assay the detection limit may be further decreased to about $0.06 \mathrm{U} / \mathrm{l}$.

2-Mercaptoethanol showed no influence on the enzyme activities, thus permitting analyses of sera stored with thiol-containing reagents as additives. Dilution of the samples with bovine serum albumin, inactivated human serum or sodium chloride solution generally resulted in increasing rates of recovery of the creatine kinase activity. On the other hand, the linearity of the bioluminescent assay yielded excellent values up to a volume fraction of serum of at least 0.08 . Therefore the increase of recovery in the dilution experiment is apparently caused by reactivation of the creatine kinase during storage after dilution. The linear relation between sample volume and enzyme activity shows that the bioluminescent assay 
is well suited to measure creatine kinase $\mathrm{MB}$ activities in a range of below $1 \mathrm{U} / \mathrm{I}$ to at least $450 \mathrm{U} / \mathrm{I}$ and therefore fulfills the requirements needed for the diagnosis of myocardial infarction (9).

Although the concentrations of the substrates ADP and phosphocreatine as well as the concentrations of the adenylate kinase inhibitors are very different in the bioluminescent and spectrophotometric assays, we did not find any discrepancies in the measured enzyme activities for total creatine kinase or for the $\mathrm{MB}$ isoenzyme. Even at low creatine kinase MB activities both assays correspond very well, but at creatine kinase $\mathrm{MB}$ activities below $10 \mathrm{U} / \mathrm{l}$ imprecision of the spectrophotometric assay increases rapidly making comparisons difficult.

\section{References}

1. Lang. H. (ed.) (1981) Creatine kinase isoenzymes, Springer Verlag Heidelberg.

2. Lundin, A., Jäderlund, B. \& Lövgren, T. (1982) Clin. Chem. 28. 609-614.

3. Würzburg, U., Hennrich, N., Lang, H., Prellwitz, W., Neumeier. D. \& Knedel, M. (1976) Klin. Wochenschr. 54. $357-360$.

4. Jung. K., Neumann, R., Cobet, G., Nugel, E. \& Egger, E. (1979) Clin. Chim. Acta 9I, 165-168.

5. Mercer, D. W. \& Varat, M. A. (1975) Clin. Chem. 21, 1088-1092.
In the manual procedure the high sensitivity and precision of the bioluminescent assay for creatine kinase MB necessitates several pipetting steps and a strict time schedule. A mechanized system should circumvent these drawbacks and make the bioluminescent assay suited for routine or stat analyses in the laboratory. Diagnostic improvements with respect to earlier confirmation or denial of acute myocardial infarction, which may arise from this highly sensitive assay, have still to be investigated.

\section{Acknowledgement}

This evaluation was supported by LKB, Technisches Büro Karlsruhe.

6. Stein, W., Bohner, J., Steinhardt, R. \& Eggstein, M. (1982) Clin. Chem. 28, 19-24.

7. Empfehlungen der Deutschen Gesellschaft für Klinische Chemie (1977) J. Clin. Chem. Clin. Biochem. 15, 249-254.

8. Haeckel, R. (1982) J. Clin. Chem. Clin. Biochem. 20, $107-110$.

9. Gerhardt, W., Waldenström, J., Horder, M., Hofvendahl, S., Billström, R., Ljungdahl, R., Berning, H. \& Bagger, P. (1982) Clin. Chem. 28, 277-283.

Dr. Dr. Wolfgang Stein

Medizinische Universitätsklinik IV

D-7400 Tübingen 